DOI: $10.17516 / 1997-1370-0826$

УДК $378+37.04$

\title{
Promotion of Social Values Among Young People as a Pedagogical Ideology (a Case Study of Russia and Kazakhstan)
}

\author{
Lyailya S. Syrymbetovaa, Laura M. Muratova*b, \\ Olga G. Smolyaninova', Zhanbol O.Zhilbaeva \\ and Zaru K. Kulsharipova \\ a Pavlodar Pedagogical University \\ Pavlodar, Kazakhstan \\ ${ }^{b}$ Karaganda University named after academician E. A. Buketov \\ Karaganda, Kazakhstan \\ 'Siberian Federal University \\ Krasnoyarsk, Russian Federation
}

Received 19.07.2021, received in revised form 10.08.2021, accepted 30.08.2021

\begin{abstract}
The article deals with the promotion of national values among students in the context of pedagogical ideology. The authors are convinced that the understanding of ideology is not limited to politics and standards of sociality. In their view, ideology is broader than a means of legitimizing power claims or political expansion, it means having a core value. In the pedagogical context, ideology is a set of social and pedagogical values for building the desired society. In this context, the promotion of social values among students is a systematic set of tools for the realization of pedagogical goals and the formation of social ideals.

In the era of globalization, social values are undergoing a significant rethinking. In this context, the problem of promoting universal and national values should be solved in their dialectical unity. In this regard, the authors of the given article have conducted a comparative study of the level of involvement in social values among representatives of universities in Russia and Kazakhstan. The authors have a little deeper outlined the features of the formation of social values in Kazakhstan, in which nowadays a system of social values has been set at the national level, which was set out in the program article of the First President of Kazakhstan, Nursultan Nazarbayev, «Looking to the future: modernization of public consciousness». This program, known as the «Rukhani Zhangyru» spiritual revival program, was launched in 2017. But so far, the values of the «Rukhani Zhangyru» program have not been given a pedagogical interpretation that would allow us to present a holistic conceptual picture of their promotion in the university environment.

This is evidenced by a number of studies, including the study and analysis of various publications in the media (mass media, central and regional newspapers), a survey among
\end{abstract}

(C) Siberian Federal University. All rights reserved

* Corresponding author E-mail address: laura.muratova@mail.ru 
teachers and students of a number of universities in Russia and Kazakhstan. The results of these studies, detailed in this article, allowed the authors to draw conclusions about the feasibility of developing a holistic concept for promoting the values of the «Rukhani Zhangyru» program in the university environment. Meeting the requirements of the pedagogical ideology, the proposed concept can be applied in any university in Russia and Kazakhstan with a certain degree of its adaptation to the specific conditions of each individual university.

Keywords: spiritual revival, student youth, university environment, social and pedagogical values, promotion of values, pedagogical ideology.

The article was prepared within the framework of the scientific project AP08957310 Mechanisms and strategies for promoting the values of «Rukhani Zhangyru» in higher education institutions of Kazakhstan under the grant funding of the Ministry of Education and Science of the Republic of Kazakhstan.

Research area: pedagogy. J. Sib. Fed. Univ. Humanit. soc. sci., 14(9), 1365-1387. DOI: 10.17516/1997-1370-0826

\title{
Продвижение социальных ценностей в молодежной среде как педагогическая идеология (на примере России и Казахстана)
}

\author{
Л.С. Сырымбетова ${ }^{a}$ Л.М. Муратовав, О.Г. Смоляниноваб, \\ Ж.О.Жилбаева , 3.К. Кульшарипова \\ "Павлодарский педагогический университет \\ Республика Казахстан, Павлодар \\ ${ }^{\sigma}$ Сибирский федеральный университет \\ Российская Федерачия, Красноярск \\ ${ }^{6}$ Карагандинский университет им. академика Е. А. Букетова \\ Республика Казахстан, Караганда
}

\begin{abstract}
Аннотация. Рассмотрены вопросы продвижения общенациональных ценностей среди студенческой молодежи в контексте педагогической идеологии. Авторы убеждены в том, что понимание идеологии не сводится к политике и стандартам социальности. По их мнению, идеология шире, чем средство легитимации властных претензий или политической экспансии, она означает наличие основной ценности. В педагогическом же контексте идеология есть набор социальных и педагогических ценностей для построения желаемого общества. В этом ключе продвижение социальных ценностей среди студенческой молодежи представляет собой системную совокупность средств для реализации педагогических целей и формирования социальных идеалов.

В эпоху глобализации социальные ценности претерпевают значительное переосмысление. В этом контексте проблема общечеловеческих и национальных
\end{abstract}


ценностей должна решаться в их диалектическом единстве. С таких позиций авторы провели сравнительное исследование уровня приобщенности к социальным ценностям представителей университетов России и Казахстана. Чуть подробнее авторы изложили особенности формирования социальных ценностей в Казахстане, где сегодня на национальном уровне задана система социальных ценностей, которая была изложена в программной статье Первого Президента Казахстана Нурсултана Назарбаева «Взгляд в будущее: модернизация общественного сознания». Данная программа, известная как программа духовного возрождения «Рухани жаңғыру», стартовала в 2017 году, но до сих пор ценностным установкам программы «Рухани жаңғыру» не дана педагогическая интерпретация, которая позволила бы представить целостную концептуальную картину их продвижения в университетской среде.

Об этом свидетельствует ряд исследований, в числе которых изучение и анализ различных публикаций в средствах массовой информации (СМИ, центральные и областные газеты), опрос преподавателей и студентов ряда университетов России и Казахстана. Результаты исследований, подробно изложенные в данной статье, позволили авторам сделать выводы о целесообразности разработки целостной концепции продвижения ценностных установок программы «Рухани жаңғыру» в университетской среде. Отвечая требованиям педагогической идеологии, предлагаемая концепция может быть применима в любом вузе России и Казахстана с определенной долей ее адаптации к конкретным условиям каждого отдельно взятого университета.

Ключевые слова: духовное возрождение, студенческая молодежь, университетская среда, социальные и педагогические ценности, продвижение ценностей, педагогическая идеология.

Статья подготовлена в рамках научного проекта АР08957310 Механизмы и стратегии продвижения ценностей «Rukhani Zhangyru» в высших учебных заведениях Казахстана при грантовом финансировании Министерства образования и науки Республики Казахстан.

Научная специальность: 13.00.00 - педагогические науки.

\section{Introduction and literature review}

Perhaps it is difficult to find a person in Kazakhstan who does not know or have not heard about the «Rukhani Zhangyru» program («Rukhani Zhangyru» program). Being aware of something, a person, as a rule, builds and shows their attitude to the subject of their awareness in a certain way.

Concerning the «Rukhani Zhangyru» program, we can safely state the ambiguity of emotional reactions, contradictory attitudes to this idea, and sometimes polar opposite opinions: if some consider it a blatant profanation, then others take a very serious part in the practical implementation of subprograms and projects. In general, the palette of emotions and relationships is very rich. This is connected, in our opinion, with the system of personal values of each person, their inner world, the strength of their faith and hope, positive or negative attitude, etc.

Therefore, in real everyday life, we often see outright attempts by many managers to pass off their regular work (festivals, sports competitions, and much more) as work on «Rukhani Zhangyru». We pay special attention to the fact that in addition to being a bit far-fetched, these are also one-time events designed for a fairly narrow range of interests. Of course, we cannot say that this is a total practice, there are also deep, well-thought-out projects.

The implementation of the Program concerns directly every citizen of Kazakhstan. This is its scale and complexity. Interpreting 
the Program from the standpoint of pedagogical ideology, we focused our research on the problems of practical implementation, more precisely, the promotion of its values in the student environment. At the same time, we are convinced that ideology is not limited to politics and standards of sociality, it is broader than a means of legitimizing power claims or political expansion, and means the presence of a basic value. In the pedagogical context, ideology is a set of social and pedagogical values for building the desired society. In this context, the promotion of social values among students is a systematic set of tools for the realization of pedagogical goals and the formation of social ideals.

\section{Theoretical framework}

The theoretical foundations of the study are the definitions of the basic concepts. Among them: «Spiritual revival», or the program «Rukhani Zhangyru», «Social values», «Pedagogical values», «Pedagogical ideology».

\section{Spiritual revival or the program «Rukhani Zhangyru»}

The program «Rukhani Zhangyru» is already in its fourth year (On the approval of the Roadmap ...; Methodological guide for the implementation of the Program...). The deadline is considerable, so there are reasons to look at the Program from today's point, stop for a while, look back and think about further actions. At the same time, it is important to decide which further direction to take: either along the path of a modern civilized society with the preservation of national culture, or along the path of developing national consciousness, rejecting everything new in favor of the original. We believe that the first option is more appropriate. One should start their journey with a conceptual, holistic understanding of program ideas. If we approach it from these positions, then the essence of the Program can be stated in three dimensions: continuity, consistency, and complexity.

The first one, i. e. continuity, means that the Program is a logical and qualitatively new continuation of «Mangilik El» ('Eternal nation') (Sem' printsipov Mangilik El..., 2014) patriot- ic act, i. e. the idea of «Rukhani Zhangyru» is not the fruit of blind chance, but is a product of common sense. Moreover, this advanced idea of modernizing the public consciousness of Kazakhstanis is subsequently supported by a program for preservation and development of the cultural code. We are talking about «Seven faces of the Great Steppe» program (Nazarbayev, 2018). We tend to see in this not a political curtsey towards the avant-garde or conservative part of the Kazakh community, but an attempt to respond to the global challenges of our time, which can be summarized as follows: today the world needs not so much knowledgeable, but thinking people who are able to think creatively and positively, act in the name of creation, self-development and self-learning.

The second dimension, i. e. consistency, demonstrates the presence of two parts in «Rukhani Zhangyru» program: theoretical and practical. The first of them proclaims six principles of modernization of public consciousness (Competitiveness. Pragmatism. Preservation of national identity. The cult of knowledge. Evolutionary, not revolutionary, development of Kazakhstan. Openness of consciousness). These principles are relevant for the spiritual revival of Kazakhstan right now, in the era of the fourth industrial revolution. Other times require other principles. For comparison, Sultan Baibars (Sultan Baibars) in the 13th century turned Egypt into a powerful nation, guided by the principles of the warrior.

The practical part of the program, consisting of six social projects (Gradual transition of the Kazakh language to the Latin script, «New humanitarian knowledge. 100 new textbooks in the Kazakh language», «Tugan Zher» ('Motherland'), «Sacred geography of Kazakhstan», «Modern Kazakh culture in the global world», «100 new faces of Kazakhstan»), is a logical continuation of the conceptual block.

Finally, the third dimension is complexity. The program is a logical set of 4 subroutines, 6 special and more than 10 basic projects.

\section{Social values}

The most recognized definition of this concept is the version given in dictionaries, in which it is interpreted in a broad and nar- 
row sense. In the first case, social values are understood as the significance of phenomena and objects of real reality from the point of view of their compliance or non-compliance with the needs of society, a social group, or an individual, and in the second, as moral and aesthetic requirements developed by human culture and are products of public consciousness. In this interpretation, it correlates with the term «social norms», which is understood as standards of activity and rules of behavior, their implementation is expected from a member of a group or society and is supported by sanctions. In addition, social norms regulate social interactions.

Especially significant for us is the opinion of O.V. Bondarenko (Bondarenko, 1998) on the division of social values into two types: terminal (universal, i. e. universal, general social, i. e. socially integrative), and instrumental (traditional and modern). If the first of them perform the role of the unifying «core», then the second perform the differentiating role. It is this position of the scientist that is directly related to the values of the Rukhani Zhangyru program.

\section{Pedagogical values}

The study of the problem of pedagogical values and their classification are devoted to the work of S.G. Vershlovskii (Vershlovskii, 1990), I. F. Isaev (Isaev, 1993), E. N. Shiyanov (Shiyanov, 1991). Scientists offer classifications of pedagogical values on different grounds. However, the interpretation of the concept of «pedagogical values» is more important for us. T. Yu. Katricheva (Katricheva, 2004) judging by the research data, believes that values reflect a socially determined and fixed orientation in the personality's psyche towards the goals of activity and the means to achieve them. The essence of this idea in the projection on pedagogical values allows to understand them as the values of a teacher, teaching staff, as well as the generally accepted human values that serve as guidelines in professional activity (Nezdaiminova, 2019, Bolotova, 2016). For our study, these positions mean that in order to promote the values of the "Rukhani Zhangyru» program in the student environment, they must necessarily become the values of the teacher and teaching staff, since it is teachers who are professional agents of socialization of children and youth.

\section{Pedagogical ideology}

The concept of ideology is usually identified with politics, with the political form of its existence. But today, both in science and in social practice, there is a clear tendency to overcome this identification. Without subjecting the presence of politics in the field of education to polemics, and recognizing the interest of political power in the implementation of pedagogical goals, «projects» and ideas, following Letyagin L. I., we tend to consider pedagogical ideology «as a system of views, ideas, values, meanings of a certain social group as 'ultimate', 'final' (Letyagin, 2014). At the same time, let us note that in pedagogy, not everything depends on ideology. But it is extremely important for us to recognize that any ideology develops around values. Taking into account the above definitions of social and pedagogical values, by «pedagogical ideology» we mean a set of these proposed for implementation and reproduction. At the same time, we agree that pedagogical values cover not only the content and goals of education, but also the methods, means and technologies of their implementation (Pantyukhin, 2014). In this aspect, the values of the «Rukhani Zhangyru» national program in their essence fully correspond to the social and pedagogical values of the modern Kazakh community. Therefore, there are full grounds to consider the promotion of value attitudes in the educational environment, including the university environment, as a pedagogical ideology. In particular, in the field of higher education, the pedagogical ideology is projected, first of all, into the ideology of high qualifications, since in modern conditions their absence guarantees a low social status. «For many, especially those who perform unskilled or low-skilled work, this work is hard, stupefyingly boring, tedious, monotonous and leads to degradation» (Gouldner, 2003). Self-improvement and self-realization in these conditions are unlikely to happen. 


\section{Methodology}

To achieve the goal of our research, we used the method of a sociological survey, as well as interviews and survey of participants to clarify individual questions and strengthen conclusions.

The conducted online survey was aimed at identifying the degree of involvement of students and teachers of a number of Kazakh universities in the values that were identified as the main guidelines for the modernization of public consciousness. The survey was conducted using the anonymous questionnaire method, which guarantees the confidentiality of the responses. Before the Google form of this survey was launched, the questionnaire was tested in one of the universities in order to check the validity and optimality of the volume of questions, the correctness and brevity of their wording. Respondents were given the opportunity to choose the language of the questionnaire: Kazakh and Russian. Therefore, the survey allows to compare the responses of Kazakh- and Russian-speaking respondents. Here, one feature should be also noted: Kazakh language is usually chosen by Kazakhs in Kazakhstan, while Russian language is chosen by representatives of all other Kazakhstani ethnic groups (there are more than 130), including Kazakhs, since there are many Russian-speaking people among them. Our research does not pursue the direct goal of studying the ethnic aspects of the problem under consideration, but the results of the survey can be considered in terms of ethnopedagogy and ethnopsychology. In other words, we see this as promising for our research, which is important for the development of certain scientific areas. In addition, the survey was organized in such a way that we had an opportunity to draw another comparative line: the responses of students and the responses of teachers. This gives a more detailed picture for a verified generalization of the information received.

Compiling the questionnaire, methodological errors were eliminated as much as possible, so there are grounds to say that the information received will not be distorted. The questions were compiled in such a way as not to compli- cate the technological procedures for collecting and processing the flow of information.

Eight questions of the questionnaire out of 9 were of closed type, while one question was aimed at ranking:

1. In your opinion, is education the main factor of your success?

2. Who do you consider yourself in the first place?

3. Rank the factors of personal competitiveness from 1 to 6 (where 1 is the minimum important factor, and 6 is the most important factor)

4. «Are the following aspirations typical for you?»

5. Are you familiar with the Program Article of the President of the Republic of Kazakhstan «Looking to the future: Modernization of public consciousness»?

6. Are you aware of the projects implemented within the framework of the «Rukhani Zhangyru» program?

7. Do you think that knowledge of these projects contributes to changing the public consciousness of Kazakhstanis?

8. Do you think that the state policy conducted in Kazakhstan contributes to the formation of interethnic harmony and tolerance of young people?

9. In your opinion, which of the above factors can contribute to the progressive development of Kazakhstan in the near future?

When launching the online survey, the sample population was representative due to the fact that the respondents included students and teaching staff of four Kazakh universities from three regions: northern, western and central Kazakhstan, as well as two universities of the Russian Federation (one federal and one private).

\section{Results and discussion}

The number of respondents was distributed as follows (Table 1):

At the same time, more than half of the survey participants were Russian-speaking respondents $(54.7 \%)$, and the group of respondents from among students $(89.0 \%)$ also dominates: teachers in the survey were less active (Fig. 1). 
Table 1. Information about respondents

\begin{tabular}{|c|c|c|c|c|c|c|}
\hline \multirow{2}{*}{$\begin{array}{l}\text { Conditional name } \\
\text { of the university }\end{array}$} & \multirow{2}{*}{$\begin{array}{l}\text { Ques- } \\
\text { tionnaire } \\
\text { language }\end{array}$} & \multirow{2}{*}{$\begin{array}{l}\text { Total } \\
\text { respondents }\end{array}$} & \multicolumn{2}{|c|}{ Students } & \multicolumn{2}{|c|}{ Teaching staff } \\
\hline & & & number & proportion & number & proportion \\
\hline \multirow{2}{*}{$\begin{array}{l}\text { A } \\
\text { (Western Kazakhstan) }\end{array}$} & kaz & 0 & 0 & 0 & 0 & 0 \\
\hline & rus & 126 & 79 & 62.7 & 47 & 37.3 \\
\hline \multirow{2}{*}{$\begin{array}{l}\text { B } \\
\text { (Central Kazakhstan) }\end{array}$} & kaz & 134 & 128 & 95.5 & 6 & 4.5 \\
\hline & rus & 107 & 99 & 92.5 & 8 & 7.5 \\
\hline \multirow{2}{*}{$\begin{array}{l}\text { C } \\
\text { (Northern Kazakhstan) }\end{array}$} & kaz & 66 & 63 & 95.5 & 3 & 4.5 \\
\hline & rus & 290 & 266 & 91.7 & 24 & 8.3 \\
\hline \multirow{2}{*}{$\begin{array}{l}\text { D } \\
\text { (Northern Kazakhstan) }\end{array}$} & kaz & 927 & 848 & 91.5 & 79 & 8.5 \\
\hline & rus & 840 & 733 & 87.3 & 107 & 12.7 \\
\hline \multirow{3}{*}{ TOTAL } & kaz & 1,127 & 1,039 & 92.2 & 88 & 7.8 \\
\hline & rus & 1,363 & 1,177 & 86.4 & 186 & 13.6 \\
\hline & total & 2,490 & 2,216 & 89.0 & 274 & 11.0 \\
\hline
\end{tabular}

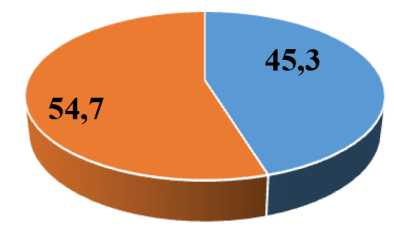

- Kazakh-speaking respondents

- Russian-speaking respondents

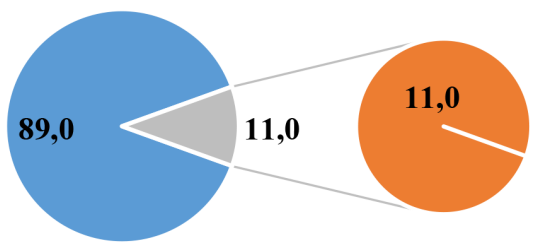

- Students - Teaching staff

Fig. 1. Information about Kazakhstani respondents (in Russian) in proportion

The study on the Russian perspective involved respondents studying at the second stage of higher education - the master's level. The overwhelming majority of respondents major in the humanities and belong to various age categories from young people (22-35 years old) to elderly people (49-56 years old). Overall, 77 respondents from Russia took part in the Google survey. The sample is considered representative.

The first question of the questionnaire was introductory and was aimed at identifying the respondents' attitude to higher education. If we take into account that all the survey participants are studying at universities, then some confusion is appropriate, since $18.6 \%$ of respondents do not consider higher education as the main factor of their success in life (Fig. 2). At the same time, the teachers' responses were quite predictable: the share of teaching staff who answered this question positively is higher than in the same group of respondents from among students $(91.9 \%: 80.2 \%=0.9: 0.8)$. It should be noted that, judging by the answers to this question, a more focused study of the situation where higher education in the system of personal values is more demonstrated by Kazakh-speaking respondents (85.9 \%:76.5 \%) is required.

A comparative analysis of the answers of Russian respondents shows a significant difference, since only slightly more than half of the respondents $(58.4 \%)$ associate their success with having a higher education diploma, while the share of negative answers to this question was $26 \%$ (Fig. 2.1).

Due to the discovered difference, we conducted an express interview with teachers and 


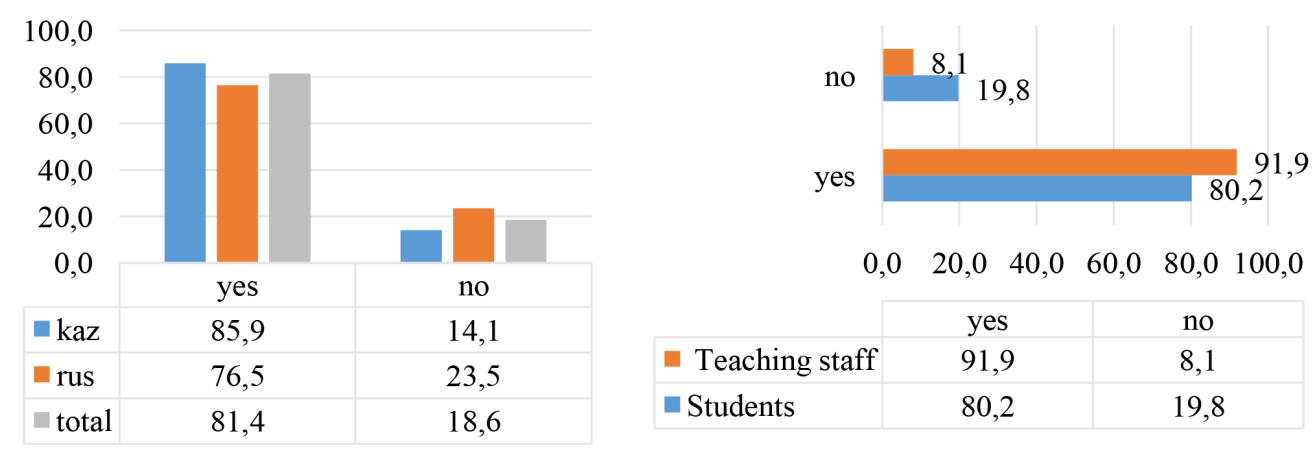

Fig. 2. Percentage of Kazakhstani respondents' answers to the question «Do you think education is the main factor of your success?»

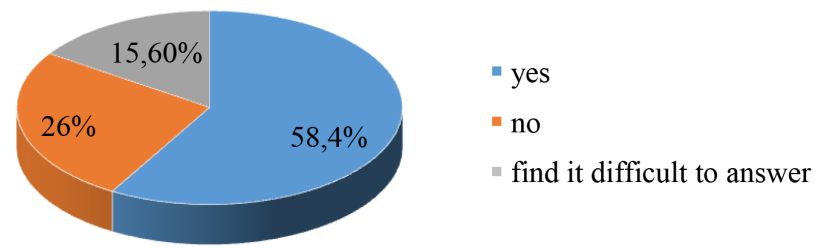

Fig. 2.1. Answers of Russian respondents to the question «Do you think education is the main factor of your success?» (in \%)

scientists who did not raise much concern, explaining this by the fact that today many of the respondents have undergone various advanced training and retraining courses, expanding the range of soft competencies formed in the framework of formal education. The need for lifelong learning in the Life Long Learning paradigm indicates that traditional higher education is experiencing a crisis at the present stage of society's development and is entering competition for consumers of high-quality educational content with non-formal and informal education provided by various stakeholders.

Respondents who found it difficult to answer the given question are still pondering on its exclusivity in order to build successful horizons for the future.

In our opinion, it is necessary to correct the question asked in order to clarify what kind of higher education we are talking about: the second, postgraduate (master's degree, in particular), postgraduate (advanced training) or about higher education as the only (not just basic) factor of success.
In general, we can talk about a general tendency of a decrease in demand for only a higher education diploma due to its non-recognition as the only condition for achieving success. It can be assumed that the existential meaning of success for university representatives is associated with deeper components of the success of a modern person (family, friends, work, money, love, leisure).

The next question of the questionnaire was aimed at identifying the degree of social selfidentification of university students and teachers, which in many respects is a key position for the development of public consciousness of Kazakhstanis and determines their commitment to national values. Here, we interpret the picture as favorable, since the majority of respondents $(61.0 \%)$ consider themselves a citizen of Kazakhstan (Fig. 3).

The possibility of choosing several or additional answers $(9.3 \%$ of respondents call themselves mainly a person, a free person, an individual $\backslash$ a human) allows us to judge the prevalence of civil self-identification in the minds of students and university teachers, the 


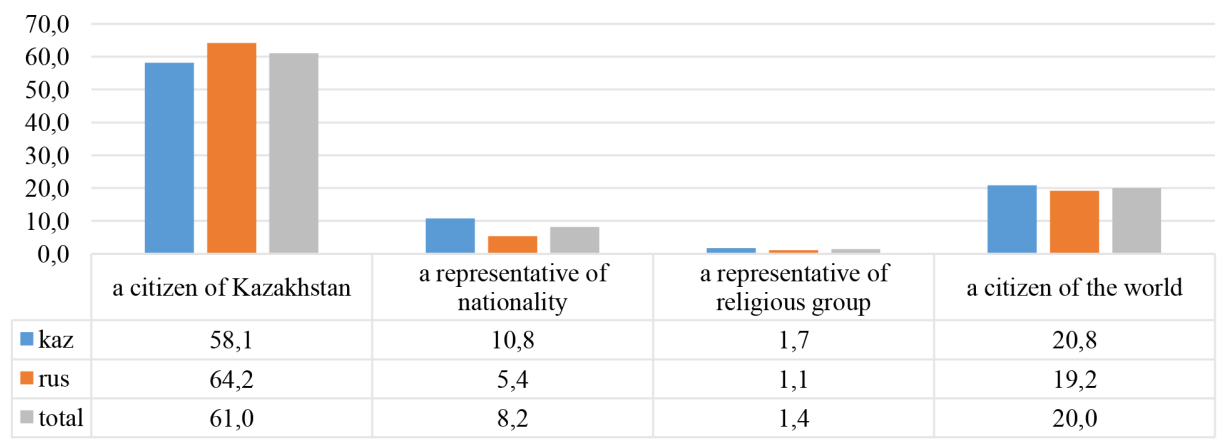

Fig. 3. Percentage of Kazakhstani respondents' answers to the question «Who do you consider yourself in the first place?»

perception of Kazakhstan as a common home for representatives of various faiths and more than a hundred Kazakh ethnic groups.

At the same time, Russian-speaking respondents show less commitment to their ethnic roots $(5.4 \%: 10.8 \%)$.

Kazakh-speaking respondents, as it turned out during the interview (in addition to the survey, we conducted an interview on this issue, since the phenomenon of personal identity itself, according to experts in the field of the fourth industrial revolution (Schwab, 2016), is undergoing a certain transformation in the modern world), there is a variety of identities: many representatives of this group of respondents, perceiving their homeland as a common home for all citizens of Kazakhstan, also choose their ethnic group as a reference.

Regarding the fact that a fifth of the respondents $(20.0 \%)$ consider themselves to be citizens of the world: this question was also asked during the interview. The opinions of the interview participants coincided in terms of what they mean by this concept. They are unanimous in the opinion that «a citizen of the world is the one who, first of all, sees himself not as a representative of any state, tribe or people, but as a representative of the human race, and the one who is ready to act on the basis of these beliefs to find solutions to the most complex world problems (Hugh Evans..., 2016). In essence, these are global problems, and they can only be solved with the participation of the world's citizens, who demand global solutions from their leaders» (On the approval of the Roadmap...).
Based on this, this indicator $(20.0 \%)$ can be interpreted as a positive self-identification. As a positive trend, we can also note the indicator of respondents' adherence to a certain religious group, since their share tends to a minimum of $1.4 \%$. In the context of a comparative analysis of the responses of teachers and students, data on the self-identification of respondents with world citizens showed that the older generation of Kazakhstanis is more conservative and pragmatic about the possibilities of solving problems at the global level (Fig. 3.1)

University teachers identify themselves as citizens of Kazakhstan to a greater extent than students $(71.5 \%: 59.8 \%)$, but the ethnic identity is demonstrated by an almost equal share of teaching staff and students (8.1\%:8.2\%).

In general, understanding selfidentification as a stable identification with any (large or small) social group or community, acceptance of its goals and value system, awareness of oneself as a member of this group or community (The meaning of the word «selfidentification»...), we believe that the respondents' answers to this question of the questionnaire show a positive trend for Kazakhstan, when one of the values of the modernization of public consciousness is the preservation of national identity. The essence of this value is that «the concept of spiritual modernization implies changes in the national consciousness. There are two points here. First, it is a change in the national consciousness. Second, it is the preservation of the inner core of the national «self» while changing some of its features» 


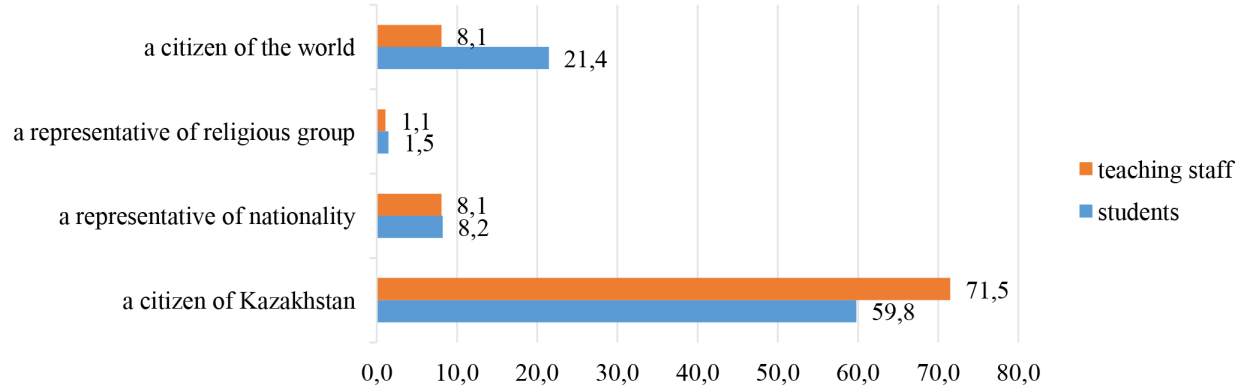

Fig. 3.1. Percentage of Kazakhstani respondents' answers to the question «Who do you consider yourself in the first place?» (comparative aspect: teachers/students, in particular)

(Nazarbayev, N.A., 2017). In other words, the modernization of public consciousness, or spiritual revival, carried out in Kazakhstan should not be considered as a transition from a national model of development to a single, universal one. The fact is that different regions and countries, as practice shows, have worked out their own development models, and national roots and national spirit are the determining factors.

Regarding the answers of the Russian respondents, it can be noted that only one third of the respondents consider themselves to be citizens of Russia. This actualizes the need for deeper research into the national and civic identities of students studying at Russian universities.

A quarter of the respondents consider themselves to be citizens of the world, which may indicate a new perception of borders, openness of education in the context of digital transformation, and globalization of the information space in the minds of this group of respondents.

The factor that unites social groups regardless their ethnicity is adherence to religion. Almost a quarter of the respondents showed themselves as representatives of a particular religion. This testifies to the presence of religious preferences and manifestations of faith in society.

The indicator of perceiving oneself as a representative of one's nationality was revealed in a small part of the respondents, only $16 \%$. This is a rather low indicator of ethnic identification, which indirectly correlates with the results of previous sociological studies among students, which showed the predominance of Russian identity over national identity in the minds of young people.

Along with this, only $1 \%$ of the respondents perceive themselves as just a person, which indicates the practical absence of this category in self-awareness (Fig. 3.2).

The next question of the questionnaire was related to the understanding of the competitiveness of an individual and was aimed at identifying the most important, in the opinion of respondents, qualities of such a person. The study of a number of scientific works, the analysis of the definitions that were given by researchers to this concept, allowed us to identify the following qualities necessary for the competitiveness of the individual: 1) timely achievement of the final result; 2) sociability, ability to cooperate; 3) stress resistance, ability to overcome difficulties; 4) working capacity, ability to professional growth; 5) knowledge of foreign languages; 6) computer literacy.

We identify the first four qualities basing on the unanimous opinion of experts in the field of becoming a competitive personality, where the most significant are orientation to a socially significant result of activity and responsibility for it; conscious focus of the individual on a certain result, the ability to set clear goals and follow them in the activity; awareness and value attitude to the social significance of the result of the activity, as well as ensuring its achievement on their own. 


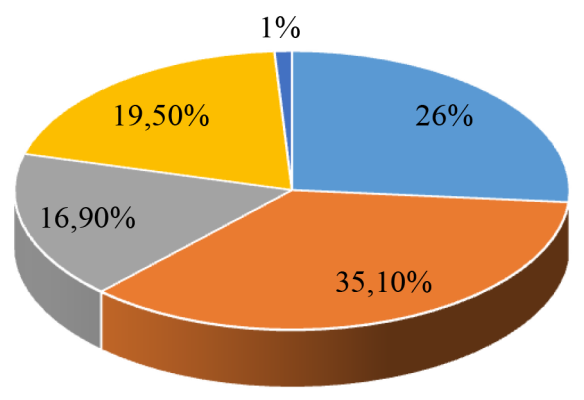

\author{
" a citizen of the world \\ - a citizen of Russia \\ - a representative of \\ nationality \\ - a representative of religious \\ group \\ - a human being
}

Fig. 3.2. Answers of Russian respondents to the question «Who do you consider yourself in the first place? (one choice)»

The main mechanism for achieving this goal, according to the researchers, is communication. Therefore, for the competitiveness of a person, the ability to act taking into account the interests, goals, and characteristics of those with whom they interact is very important. Therefore, we have identified such qualities as sociability and the ability to cooperate.

Stress tolerance, the ability to overcome difficulties, in our opinion, are the guarantee of successful adaptation of a person in the «no comfort» zones, which are characteristic of the modern world of instability, uncertainty, complexity and ambiguity.

Moreover, for a successful and adequate competition, a person, of course, needs to develop such qualities as efficiency and the ability to advance professional growth.

We firmly believe that the last two qualities are necessary for the formation of a competitive personality in the context of the general trends in the development of modern Kazakh society. Almost none of the available scientific sources mention these qualities directly, unambiguously and so specifically, but for the successful implementation of professional activities in the realities of the Kazakh labor market, they are of lasting importance.

Before testing the questionnaire that we developed, this question assumed the choice of other qualities that indirectly affect the competitiveness of a person. But the analysis of the results of the approbation confirmed us in the opinion that it will be enough to indicate the six above-mentioned factors of personal competitiveness in the answers to this question.
Therefore, we present an analysis of the answers to the question «Rank the factors of personal competitiveness from 1 to 6 (where 1 is the least important factor, and 6 is the most important factor)». In Figures 4 and 4.1, these factors are conventionally indicated by numbers: I-efficiency, ability to professional growth; II-sociability, ability to cooperate; III-stress resistance, ability to overcome difficulties; IV-timely achievement of the final result; V-knowledge of foreign languages; VI-computer literacy.

According to respondents, the most important factors of personal competitiveness (Fig. 4) are stress resistance, the ability to overcome difficulties $(44.7 \%$ of respondents gave the maximum six points to this factor) and computer literacy $(44.0 \%)$. At the same time, Russian-speaking respondents $(45.6 \%)$ emphasize such factors as sociability and the ability to cooperate. The smallest share of respondents (31.1\%) choose such a factor as knowledge of foreign languages.

A slightly different picture is formed when comparing the responses of students and teachers (Fig. 4.1). Here, the largest share of respondents gave the maximum six points to such factors as efficiency and ability to professional growth $(62.4 \%$ of teaching staff) and sociability, ability to cooperate $(61.3 \%$ of teaching staff). Also important for the older generation are stress tolerance, the ability to overcome difficulties (59.7\% teaching staff) and computer literacy $(57.5 \%$ of teaching staff). Respondents from among students prefer stress resistance and ability to overcome 


\begin{tabular}{|c|c|c|c|c|c|c|}
\hline 睯园 & $+1-1=$ & $y^{2}-z^{2}$ & $x^{2}=$ & ${ }^{2}+1=$ & $-1=$ & 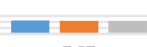 \\
\hline & I & II & III & IV & V & VI \\
\hline a kaz & 42,5 & 39,5 & 42,8 & 41,7 & 33,0 & 44,9 \\
\hline$\square$ rus & 43,1 & 45,6 & 46,7 & 41,8 & 28,9 & 43,1 \\
\hline$\square$ total & 42,8 & 42,4 & 44,7 & 41,8 & 31,1 & 44,0 \\
\hline
\end{tabular}

Fig. 4. Percentage of Kazakhstani respondents' answers to the question «Rank the factors of personal competitiveness from 1 to 6 by the degree of importance for you»

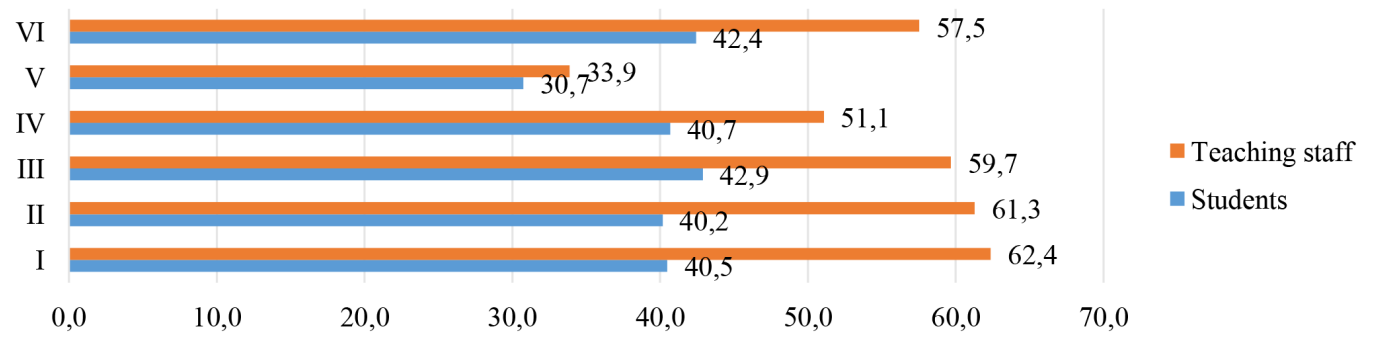

Fig. 4.1. Percentage of Kazakhstani respondents' answers to the question «Rank the factors of personal competitiveness from 1 to 6 by the degree of importance for you»

difficulties in the list of competitiveness factors $(42.9 \%)$.

It should be noted here that the factors of personal competitiveness chosen by the respondents meet the requirements of the time, for which «soft» skills are important. Sometimes they are more important than hard (or 'professional' in our interpretation) skills (Zhetpisbayeva et al., 2020). It is quite puzzling that among the factors of human competitiveness that we have indicated, knowledge of a foreign language does not occupy top places in the ranking. Based on the analysis of the answers to this question, we can recommend that the leadership of Kazakhstan's universities pay attention to the need to strengthen measures to improve students' and teachers' computer literacy, as well as the formation of their stress resistance and ability to work in a team, more precisely take into account the opinion of their students and teachers when organizing advanced training courses for teaching staff and building the educational trajectory of students.

The results of the study of a group of experts, among which the course of distance learning of computer science teachers draws attention, are crucial in this aspect. The significance of this study lies in the fact that the course proposed by the authors can be fully applied in the educational process of universities, thereby contributing to the development of computer literacy of students (Mukasheva et al., 2020), which is considered by many to be one of the important factors of the competitiveness of modern people.

All these factors of competitiveness fully reveal the essence of the concept of «flexible skills», which together with professional ones make up the so-called «soft and hard skills». In particular, for a single-profile pedagogical university, this opens up prospects for the development and implementation of such minor programs as «Mediation in Education», «Management in Education», «Information Technologies in Education», "Art Technologies in Education», «Business and Entrepreneurship in Education», etc. This list of additional programs can be continued, taking into account the specifics of a particular (other than pedagogical) direction of training specialists.

These recommendations, taking into account the answers to the following question, can make their own adjustments not only in innovative, but also in traditional (classical) academic disciplines of educational programs. In particular, to develop and support 
such aspirations of students as achieving their goals taking into account their capabilities $(92.0 \%)$ and caring for nature and ecology $(91.7 \%)$. These two aspirations were the most characteristic of our respondents (Fig. 5). However, in our opinion, we should also pay attention to the formation of such qualities as efforts to lead a healthy lifestyle $(85.9 \%)$ and to be successful in school (83.6\%). At the same time, quite an alarming point is associated with a noticeable difference in the indicators of Kazakh-speaking and Russianspeaking respondents: the low aspiration for success in learning among the latter (78.6\%). We are sure that this indicator needs more indepth study, taking into account the ethnopsychological aspects of education in Kazakh universities.

Note that this quality was also demonstrated by the lowest proportion $(39.2 \%)$ of respondents from among university teachers (Fig. 5.1).
There is a certain pattern in this: higher motivation in education for those students whose teachers themselves know how to learn and study. This is the power of personal example - students, even as students, imitate their teachers.

It should also be noted that these data correlate with the general picture of professional development of teachers of Kazakhstani universities. Additional interviews with the heads of the institutes (centers) of advanced training of the four universities where this survey was conducted, indicate a formal approach of the majority of students from among the teaching staff to the ongoing advanced training courses: they need certificates only to pass the next certification, which is usually held once every five years. We believe that this aspect of our research should be the subject of special attention of the heads of higher educational institutions.

Analyzing the answers of Russian respondents, we can conclude that the overwhelming

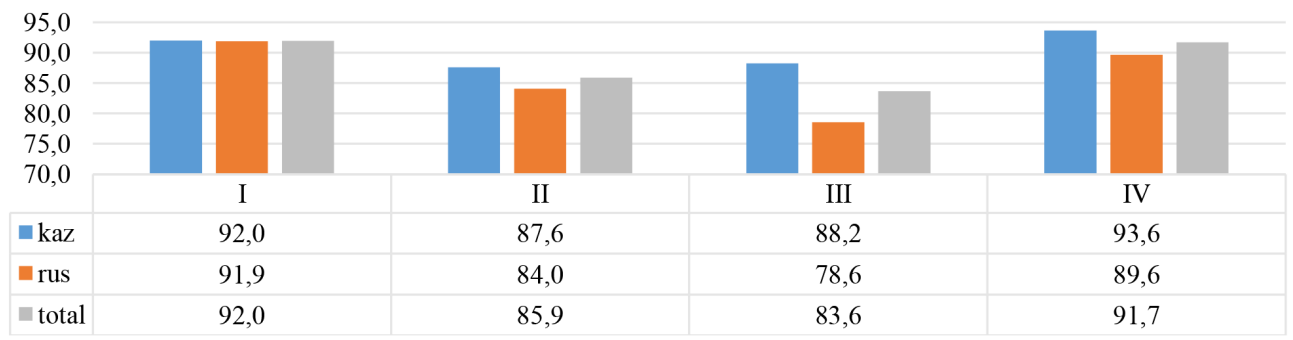

Notes to the figure: I. I try to achieve my goals based on my capabilities; II. I lead a healthy lifestyle; III. I try to be successful in my studies; IV. I take care of nature, ecology

Fig. 5. Percentage of Kazakhstani respondents' answers to the question «Are the following aspirations typical for you?»

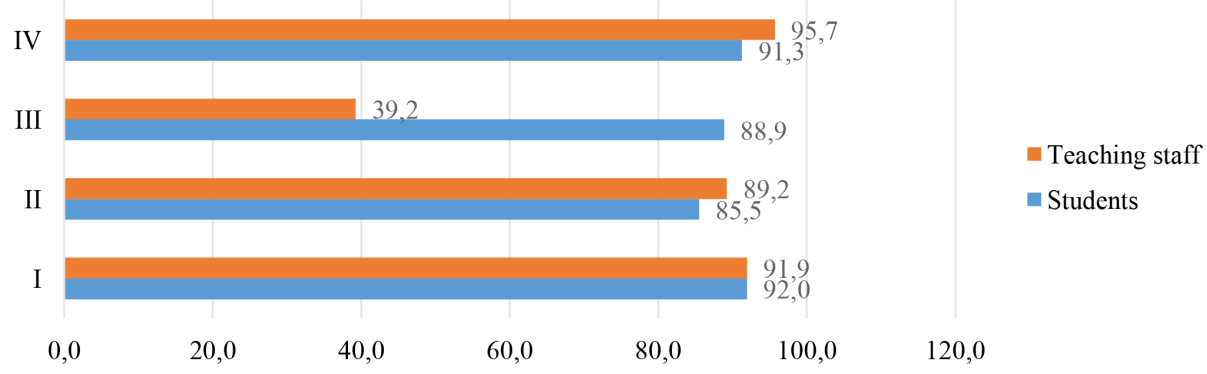

Notes to the figure: I. I try to achieve my goals based on my capabilities; II. I lead a healthy lifestyle; III. I try to be successful in my studies; IV. I take care of nature, ecology

Fig. 5.1. Percentage of Kazakhstani respondents' answers to the question «Are the following aspirations typical for you?» 
majority of respondents strive to treat nature and ecology with care, which can be regarded as a positive component of the social portrait of Russians. One can note the purposefulness of the respondents, who, when achieving goals, take into account their capabilities as a positive situation as well.

Only half of the respondents adhere to a healthy lifestyle, which is a disappointing indicator. It indicates a low degree of awareness of the need to monitor one's physical health. An alarming situation is developing in the motivation of education, since half of the respondents who are representatives of universities do not particularly strive for academic success. However, these answers correlate with the answers to the question «Is higher education the main factor of your success?»

If the first five questions of the questionnaire are asked in the general context of the modernization of public consciousness, then the following questions are directly related to the "Rukhani Zhangyru» program. As we have already noted, the program article of N. Nazarbayev identified the main vectors of development that are strategically important for the modern Kazakh community. Therefore, during the survey, it was absolutely natural to clarify how well our respondents are aware of this article. Despite the fourth year of implementation of «Rukhani Zhangyru» national program (starting from 2017), with the materials of the article of the First President of Kazakhstan called «Looking to the future: modernization of public consciousness», among the respondents were those who were not familiar with this article (Fig. 6), not only among students (15.5\%), but also among teachers (11.8\%) of universities.

Note that in the comparative aspect, the responses of Kazakh- and Russian-speaking

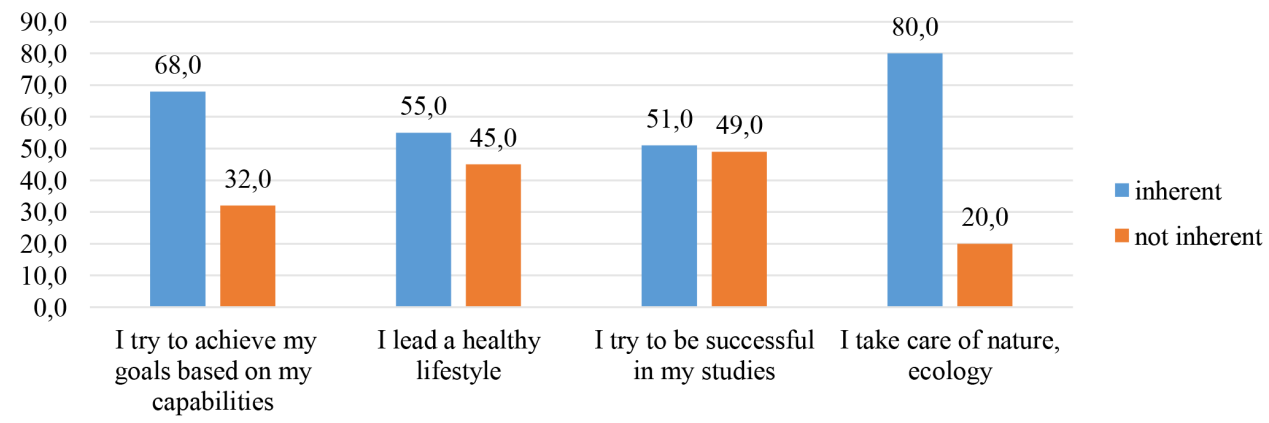

Fig. 5.2. Answers of Russian respondents to the question «Are the following aspirations typical for you?» (in \%)

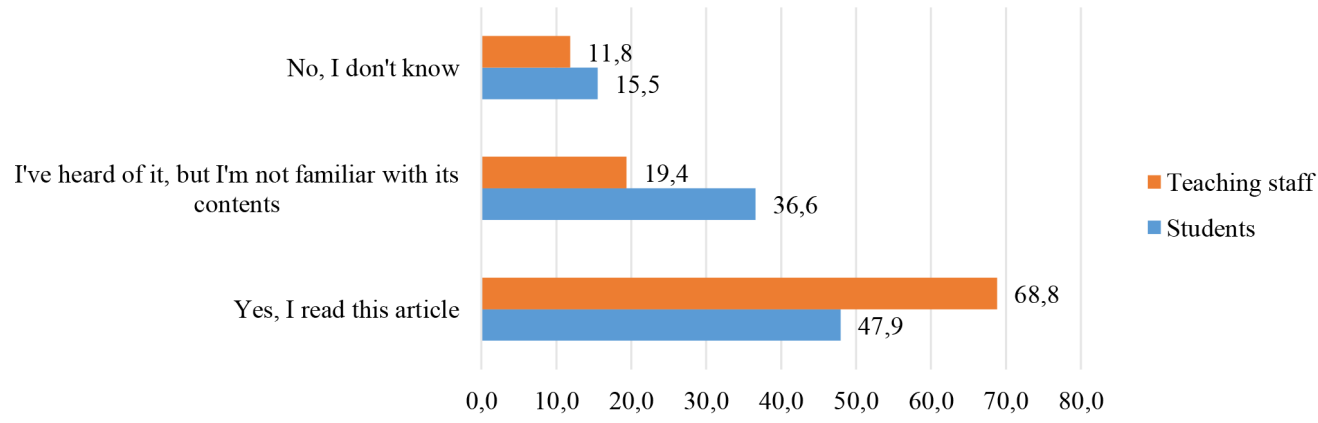

Fig. 6. Percentage of Kazakhstani respondents' answers to the question «Are you familiar with the Program article of the First President of the Republic of Kazakhstan «Looking to the future: modernization of public consciousness»?» 
respondents do not have a significant difference (Fig. 6.1).

If we take into account that a third of the respondents admit to ignorance of the content of this program article, then the university management is strongly recommended to step up work to promote the values of spiritual modernization of the Kazakh community. This is important for the further socio-economic and cultural development of the country as a whole. We once again emphasize the strategic importance of this program for the successful social adaptation of Kazakhstanis to the conditions of an extremely volatile world full of uncertainty, instability and impermanence.

Regarding the basic projects of this program, the survey results revealed the greatest interest of respondents to «Transition of the Ka- zakh language to the Latin alphabet» (52.6\%) and «100 new Faces of Kazakhstan» (50.8\%) projects, of the least interest (36.8\%) is «Tugan Zher» project, and it is the least popular among Kazakh-speaking respondents (Fig. 7).

In the comparative aspect, the answers to this question show that teachers are more aware of the projects implemented within the framework of the «Rukhani Zhangyru» program than students (Fig. 7.1).

This information gives real chances to use the potential of the teaching staff for more active promotion of the values of «Rukhani Zhangyru» in the university environment, not only among young people, but also among adult representatives of the university community.

A more positive picture can be observed when analyzing the respondents' opinions

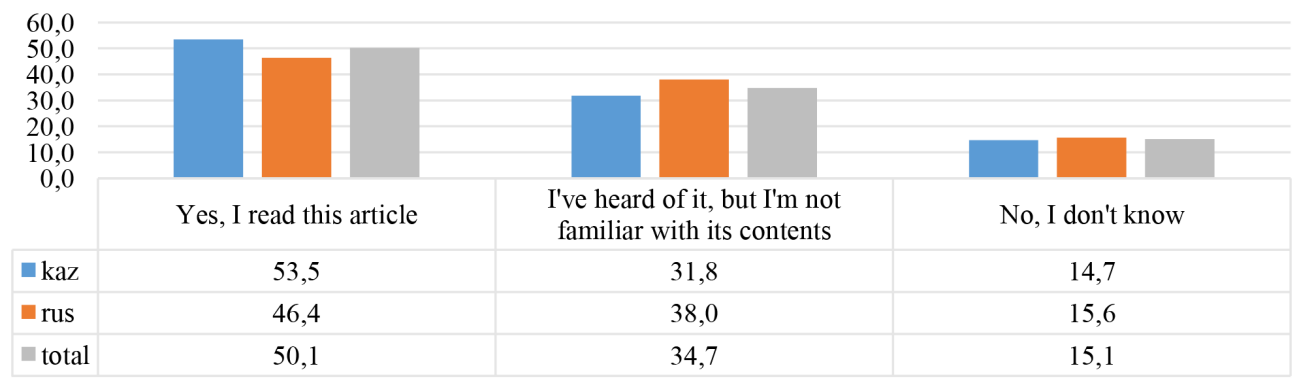

Fig. 6.1. Percentage of Kazakhstani respondents' answers to the question "Are you familiar with the Program article of the First President

of the Republic of Kazakhstan «Looking to the future: modernization of public consciousness»?»

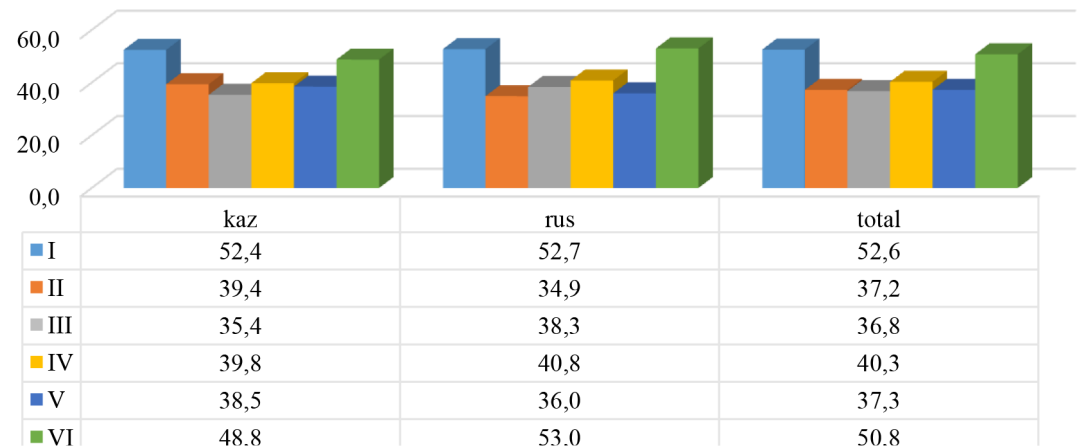

Notes to the drawing: I. «Transition of the Kazakh language to the Latin alphabet»; II. «New humanitarian knowledge. 100 new textbooks in the Kazakh language»; III. «Tugan Zher» Program; IV. «Spiritual shrines of Kazakhstan» or «Sacred geography of Kazakhstan»; V. «Modern Kazakh culture in the global world»; VI. «100 new faces of Kazakhstan»

Fig. 7. Percentage of Kazakhstani respondents' answers to the question «Are you aware of the projects implemented within the framework of the «Rukhani Zhangyru» program?» 
about the effectiveness of the basic projects, their ability to influence the public consciousness. Here, the majority of respondents $(69.0 \%)$ were optimistic, regardless of the chosen language of the questionnaire (Fig. 8).

Let us make a small remark: speaking about the language of the respondents, we once again clarify that the Kazakh language of the questionnaire is chosen in Kazakhstan, as a rule, by Kazakhs, while the Russian language is chosen by representatives of all $\mathrm{Ka}$ zakhstani ethnic groups (there are more than 130 of them), including Kazakhs (there are many Russian-speaking representatives among modern Kazakhs). That is why any sociological survey conducted in two languages is of scientific interest in terms of ethnopsychology, ethnopedagogy and ethnosociology. However, the ethnic aspects of the modernization of the public consciousness of modern Kazakhstanis are not the subject of this study. It should be noted as a positive trend that both students and university teachers showed equal optimism in this issue (Fig. 8.1). Nevertheless, a certain categorical attitude of teachers is also of interest to our research, since among them a very small proportion are doubters $(5.9 \%)$. We believe that this is due to the fact that not all teachers can judge the very essence of the «Rukhani Zhangyru» program (see Fig. 6 above).

In contrast to the previous question, the respondents' opinions on the impact of the state policy implemented in Kazakhstan on the formation of interethnic harmony and tolerance of young people are less optimistic (Fig. 9), as only half of the respondents (46.7\%) answered

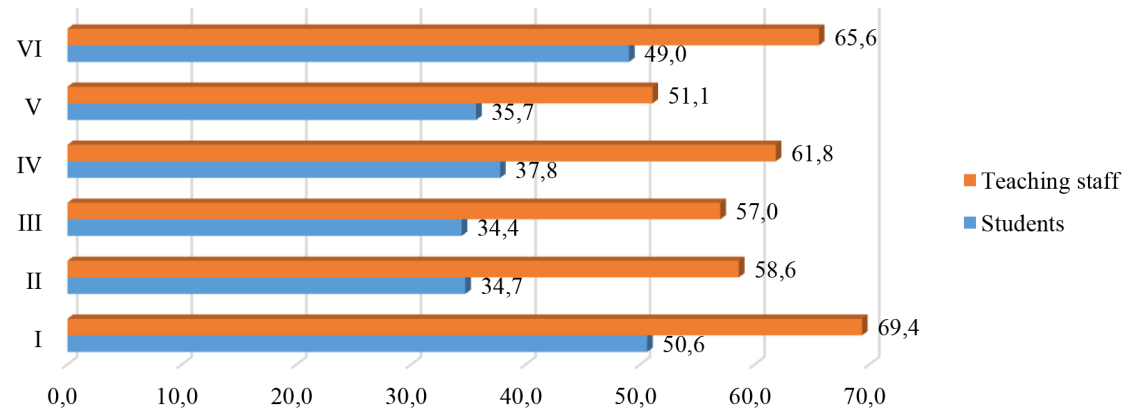

Notes to the drawing: I. «Transition of the Kazakh language to the Latin alphabet»; II. «New humanitarian knowledge. 100 new textbooks in the Kazakh language»; III. «Tugan Zher» Program; IV. «Spiritual shrines of Kazakhstan» or «Sacred geography of Kazakhstan»; V. «Modern Kazakh culture in the global world»; VI. «100 new faces of Kazakhstan»

Fig. 7.1. Percentage of Kazakhstani respondents' answers to the question «Are you aware of the projects implemented within the framework of the «Rukhani Zhangyru» program?»

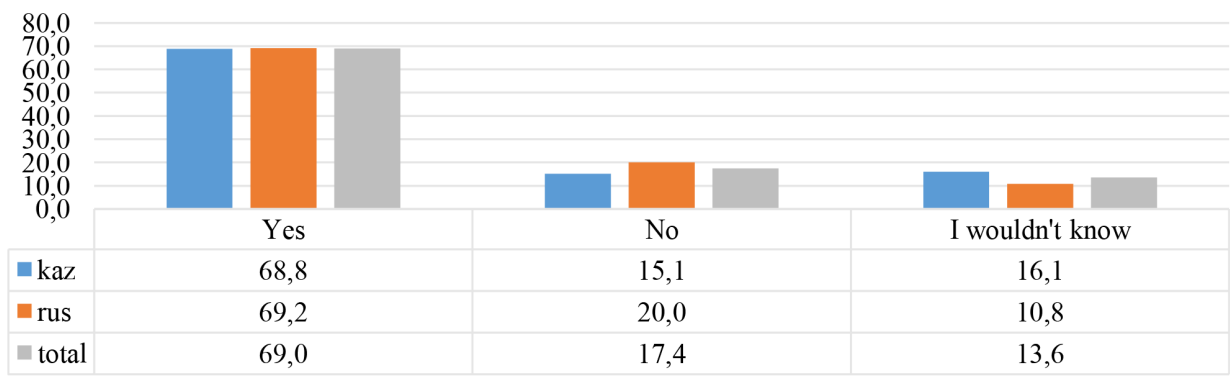

Fig. 8. Percentage of Kazakhstani respondents' answers to the question «Do you think that knowledge of these projects contributes to changing the public consciousness of Kazakhstanis?» 
in the affirmative, and the Russian-speaking respondents were more positive $(50.6 \%)$. As a positive trend in this question, we estimate the low share of negative categoricity in the responses of respondents (6.2\%). Here, a third, or $27.7 \%$, of respondents have difficulties in their answers, which once again emphasizes the non-categorical nature of the assessment of state policy in the field of interethnic harmony.

In the comparative aspect, teachers are more optimistic about this issue (Fig. 9.1), which indicates that universities have the pedagogical potential to activate the processes of spiritual revival of the Kazakh community.

Russians were asked a similar question. A third of Russian respondents believe that the state policy pursued in Russia contributes to the formation of interethnic harmony and tolerance of young people, another third note the insignificance of the government's actions in carrying out this policy. At the same time, the share of those who find it difficult to answer this question and the share of respondents who give a negative assessment of the processes of forming interethnic harmony and tolerance of young people can be assessed as an alarming trend. We also associate the latter result with low political literacy and complete indifference of a number of respondents to interethnic problems in society (Fig. 9.2).

The answers to the last question of the questionnaire were aimed at ranking the factors that, in the opinion of our respondents, can contribute to the progressive development of their countries in the near future.

Nine factors were proposed as a choice, among which the most effective, according to Russian respondents, are: 1) improving the quality of education and healthcare, 2) developing industry and infrastructure, 3) upbringing a free personality. An important factor in the progressive development of Russia and Sibe-

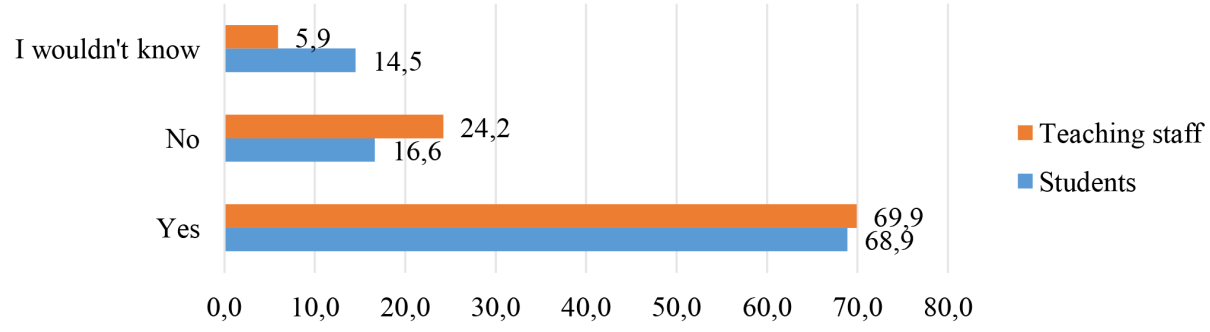

Fig. 8.1. Percentage of Kazakhstani respondents' answers to the question «Do you think that knowledge of these projects contributes to changing the public consciousness of Kazakhstanis?»

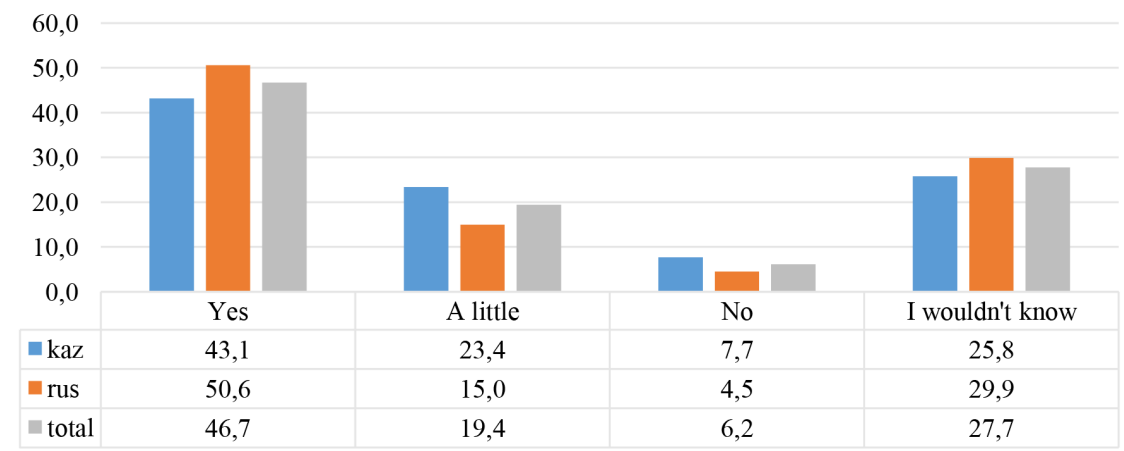

Fig. 9. Percentage of Kazakhstani respondents' answers to the question «Do you think that the state policy implemented in Kazakhstan contributes to the formation of interethnic harmony and tolerance of young people?» 


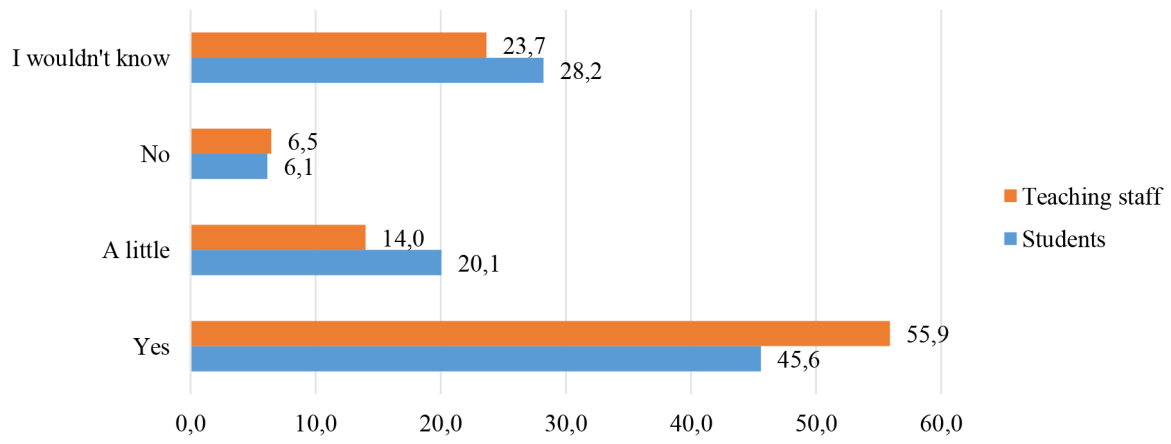

Fig. 9.1. Percentage of Kazakhstani respondents' answers to the question «Do you think that the state policy implemented in Kazakhstan contributes to the formation of interethnic harmony and tolerance of young people?»

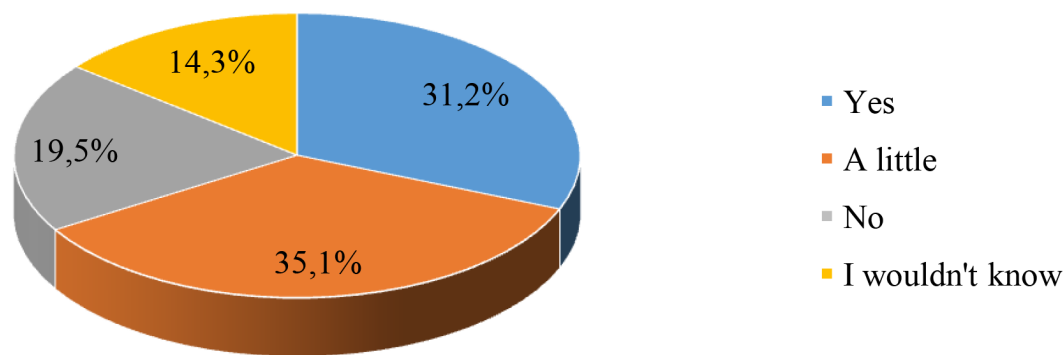

Fig. 9.2. Answers of Russian respondents to the question «Do you think the current state policy in Russia contributes to the formation of interethnic harmony and tolerance of young people?»

ria, first of all, according to the respondents, is the development of science and technology (28.6\%), civil society (26\%), and democratic institutions $(20.8 \%)$.

$16.9 \%$ of respondents believe that it is necessary to eliminate corruption for the sake of the development of Russia.

As a positive trend, one can note the low share of respondents who prefer protest movements for the development of the country. For centuries Siberia has been a multinational family for many peoples, but the share of respondents who prefer the activities of opposition parties as a factor in Russia's development is somewhat alarming (Fig. 10).

Answers of Kazakhstani respondents were ranked in descending order of importance and are shown in the following table.

Thus, the respondents consider the elimination of corruption as a factor of primary im- portance in the progressive development of Kazakhstan. This fact confirms the loyalty of the anti-corruption policy pursued in Kazakhstan (National report on anti-corruption policy...).

In the last place, the respondents placed protest movements as a factor contributing to the progressive development of Kazakhstan. This attitude of the absolute majority of respondents to conflict behavior, the manifestation of mass discontent and group negativism indicates, in our opinion, the absence of marginalized strata among the university community of Kazakhstan, as well as individuals with an increased (inadequate) level of claims (according to experts, these two categories of people mainly take part in protest movements) (Social and protest movements...). We also believe that such a negative attitude towards protest movements is traditionally characteristic of Kazakhstanis, in particular, it is characteristic 


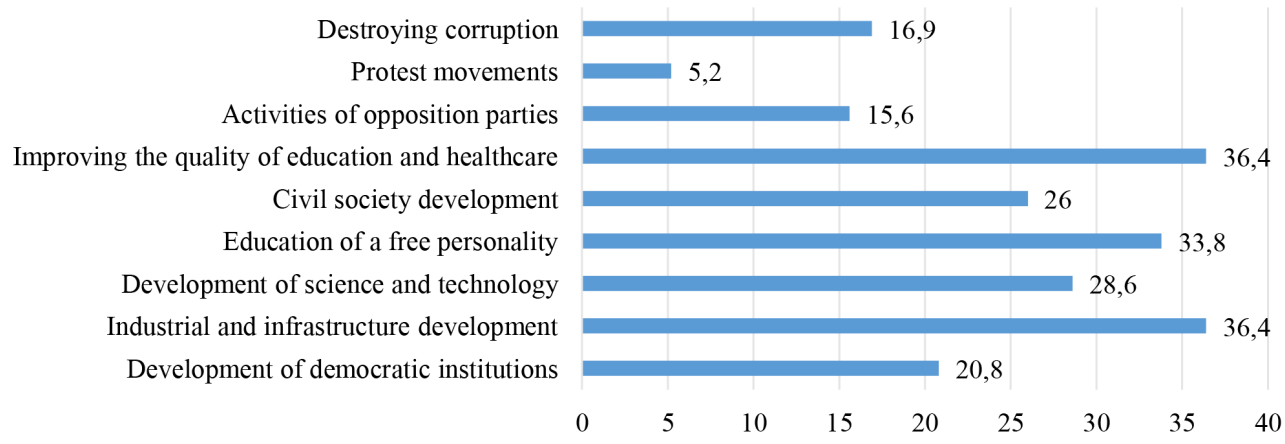

Fig. 10. Answers of Russian respondents to the question

«In your opinion, which of the listed factors can contribute to the progressive development of Russia in the near future?» (in \%)

Table 2. Ranking of factors contributing to the progressive development of Kazakhstan in the near future

\begin{tabular}{|c|l|c|c|c|}
\hline \multirow{2}{*}{ Rank position } & \multirow{2}{*}{ Factors } & \multirow{2}{*}{$\begin{array}{c}\text { Percentage } \\
\text { of respondents }\end{array}$} & Ratio of shares \\
\cline { 5 - 5 } & & 93,9 & 94,4 & 89,2 \\
\hline 1st place & Destroying corruption & 86,4 & 85,7 & 91,9 \\
\hline 2nd place & Improving the quality of education and healthcare & $\begin{array}{c}\text { Teaching } \\
\text { staff }\end{array}$ \\
\hline 3rd place & Civil society development & 81,4 & 80,9 & 85,5 \\
\hline 4th place & Development of science and technology & 56,6 & 55,1 & 69,9 \\
\hline 5th place & Industrial and infrastructure development & 55,3 & 55,5 & 53,8 \\
\hline 6th place & Education of a free personality & 39,6 & 41,4 & 24,7 \\
\hline 7th place & Development of democratic institutions & 38,0 & 37,9 & 39,2 \\
\hline 8th place & Activities of opposition parties & 14,5 & 15,4 & 7,5 \\
\hline 8th place & Protest movements & 10,5 & 11,3 & 3,2 \\
\hline
\end{tabular}

of the mentality of the titular ethnic group - the Kazakhs. This statement is not categorical, but rather axiomatic. It is impossible and impractical to give an unambiguous assessment of such complex social phenomena as protest movements. There are a lot of facets, sometimes contradictory trends. Therefore, the results of the answers to this question of the questionnaire can become a starting point for serious scientific research by sociologists.

Following the general logic of our research, we draw attention to the significant difference in the responses of students and teachers in three positions:

- education of a free personality;

- activities of opposition parties;
- protest movements.

Here, the share of respondents from among students is much higher than the share of teachers. In other words, the younger generation is more likely to believe that the education of a free person is one of the factors of the progressive development of Kazakhstan. In a conversation with several young people, we found out their general understanding of the essence of this concept. As it turned out, our interlocutors clearly understand that there is no absolute freedom of a person, even if they live outside of society (say, somewhere in the jungle, on a desert island). A free person, however, according to young people, is a person who has the opportunity to choose, who does not feel 
constant fear of possible punishment and obstacles, is aware of and accepts any restrictions and understands the need to comply with the rules and norms that regulate safe relations between people, etc.

We believe that this should form the basis for the interaction of teachers and students in the educational process of the university, and should also be legally enshrined in the internal documents regulating the activities of the university.

Regarding two other positions: the activities of opposition parties and protest movements. Based on numerous studies in the field of protest psychology, we note that the readiness for protest behavior is more characteristic of youth (Psychology of protest behavior...). The reasons, as a rule, lie in the gradual loss of fear, when you are among the constant environment of a large number of similar people. It is no coincidence that experts say that the probability of protests is higher in cities. The rapidly growing penetration of the Internet may also be a decisive factor in the further mobilization of the protest movement (Zakharov, 2013). All this is just typical for the youth environment. With age, the circle of such close and constant communication narrows. Therefore, for people of mature and elderly age, the readiness to protest is observed many times less. At the same time, protest activity in youth is mainly characterized by opposition, which is understood as rivalry, lack of desire to achieve goals, external openness in confrontation and provocative behavior, incitement. This is in contrast to the protest behavior, for example, of adolescents, who are more characterized by escapism - the transition of activity into transformative activity, and in people of mature age, this behavior is based on emancipation - the desire for autonomy, the desire to preserve the stability of the social structure.

Taking into account the above, the low probability of protest behavior of representatives of Kazakhstani universities (11.3\%) can be safely assessed as a positive trend. At the same time, the results of the survey in this aspect should also be taken into account by the management and teachers of universities.

\section{Conclusion}

In general, the results of the survey showed a heterogeneous picture of students' involvement in the values of the "Rukhani Zhangyru» program. The majority of students share the Program's ideological message, but at the same time demonstrate detachment from its specific values. We believe that this is due to the fact that many students perceive the proposed projects as something mandatory not for them, but for other people. A change in the situation can be facilitated by professional support from teachers for the formation of students' social experience to project the ideas of the Program on the personal value system.

Therefore, a detailed analysis of the answers to each question of the questionnaire is completed. However, the conducted sociological survey was important for us in order to offer more effective mechanisms for promoting the values of «Rukhani Zhangyru». Thus, based on the results of the opinion poll, we decided to develop a Concept for promoting the values of «Rukhani Zhangyru» national program among students. According to our concept, the goal of promoting the values of the Program at the university is to create the necessary conditions for the involvement of the absolute majority of students and employees of the university in the processes of modernization of public consciousness. As step-by-step actions to achieve this goal, we suggest solving the following tasks:

- analysis, explanation and popularization of the ideas mentioned in «Looking to the Future: modernization of public consciousness» and «Seven Facets of the Great Steppe» articles;

- scientific and methodological interpretation of the historical essence and significance of the ideas of «Rukhani Zhangyru»;

- scientific and methodological support for the implementation of ideas and «Rukhani Zhangyru» program directions;

- introduction of the program foundations of spiritual modernization in the educational and research activities of the university.

To solve these problems, the following provisions are proposed as principles: 
1) transition from one-time events to longterm social projects - while maintaining traditional one-time events, the promotion of the values of the "Rukhani Zhangyru» program should be carried out through long-term projects involving the vast majority of students and university staff;

2) access to the external environment - a very wide range of external stakeholders should be involved in the implementation of long-term projects (parents, friends and relatives of students and employees, applicants, domestic and foreign partners of the university, including other educational organizations, industrial enterprises, public organizations, etc.);

3) integration of the values of «Rukhani Zhangyru» in educational programs and research works-synchronization of the content of individual academic disciplines, the topics of theses, master's theses, scientific research of scientists with the ideas of modernization of public consciousness.

The details of the proposed Concept should be reflected in a special document, for example, an Action Plan related to the objectives of the Concept. Therefore, we propose to allocate such sections as:

1) scientific and methodological support for the promotion of the ideas of «Rukhani Zhangyru»;

2) scientific and methodological support for the implementation of the ideas of «Rukhani Zhangyru»;

3) social projects of the university;

4) initiative activities of departments and faculties.

In the first section of the Plan, it is necessary to provide for the implementation of research works of departments and the study of issues of spiritual modernization in the framework of theses and master's theses.

The second section of the Plan should be devoted to the issues of synchronization of the content of individual academic disciplines, primarily social and humanitarian orientation, with the ideas of «Rukhani Zhangyru».

The third section of the Plan involves the implementation of long-term projects in which all students and teachers of the university will participate. The number of such projects de- pends on the specific conditions of each university.

The fourth section of the Plan should include activities proposed by teachers, student groups, and departments. At the same time, the level of events can vary from the cathedral to the regional level.

In general, the success of the Program depends on the participation of everyone, regardless of age and gender, education and profession, national and religious identity. Here we are talking about spiritual values.

That is why the participation of every student, master's student, doctoral student, teacher and employee in the promotion of the values of «Rukhani Zhangyru» program is very important.

The existence of such a nationwide program as «Rukhani Zhangyru» indicates that modern Kazakh society has realized the need to form a new generation of Kazakhstanis who are attached to the values of spiritual revival. Thanks to this Program, Kazakhstanis received specific strategies for changing their worldview. The mechanisms for implementing the Program should be developed by the academic community, whose participation will ensure the integration of the idea of spiritual revival into the educational and research content of educational programs.

The results of the survey show an insufficient degree of formation of the majority of students of universal spiritual values necessary for life in the 21st century. This means that with sufficient awareness of the provisions of the Program, most students have not made them part of their personal system of values, goals and attitudes.

We believe that it is important to apply conceptual, systematic, and integrated approaches in promoting the Program's ideas. The proposed concept of promoting the Program's values is aimed at universities and provides for step-by-step planning of complex measures. We believe that this conceptual approach will ensure the broad involvement of students in the activities related to the Program and the measurability of the results of participation, for example, writing a final paper, participating in the volunteer movement, visiting sacred places 
in Kazakhstan, learning the Kazakh language, publishing an article about Kazakhstan in a foreign publication, preparing a film, videos with Kazakh content, etc. In the end, a balanced social portrait of a modern young Kazakhstani should be formed.

Since the «Rukhani Zhangyru» program is built on the basis of historical continuity, it will make it possible to update the centuries- old heritage of the ancestors, making it understandable and in demand in the modern life of the Kazakh society.

\section{Declarations of Ethics \\ Competing interests}

On behalf of all authors, the corresponding author declares that all authors have no competing interests.

\section{References}

Bolotova, Zh. A., Kostrikova Yu. V., Radchenko E. A., Rakhmanova, M.N. (2016). Values of Pedagogical Activity. In International Journal of Applied and Fundamental Research. 1-2, pp. 257-259. Available at: https://applied-research.ru/ru/article/view?id=8362

Bondarenko, O. V. (1998). Sotsial'nye tsennosti v sovremennom rossiiskom obshchestve: analiz sistemnykh izmenenii [Social values in modern Russian society: Analysis of system changes]. Available at: https://clck.ru/XecKf

Gouldner, A. W. (2003). The coming crisis of Western sociology. St. Petersburg, Nauka, 575 p.

Hugh Evans: What does it mean to be a citizen of the world? (2016). Available at: http://gonzo.kz/ blog/4999-hyu_evans chto_znachit byit_grajdaninom mira

Isaev, I.F. (1993). Theory and practice of formation of professional and pedagogical culture of the high school teachers. Moscow, $219 \mathrm{p}$.

Katricheva, T. Yu. (2004). The Problem of Classification of Pedagogical Values. In Uspekhi sovremennogo estestvoznaniia. 7, p. 119-120. Available at: https://clck.ru/XecLG

Letyagin, L.I. (2014). Philosophy of ideology. Yekaterinburg: Ural State Pedagogical University.

Methodological guide for the implementation of the Program «Rukhani zhangyru: a new stage». Prepared by the Department of Public Modernization of the Ministry of Public Development of the Republic of Kazakhstan (2018) Available at: https://clck.ru/XecLU

Mukasheva, M., Chorosova, O., Zhilbayev, Zh., \& Payevskaya, Y. (2020). Integrated approach to the development and implementation of distance courses for school computer science teachers. 2020 IEEE14th International Conference on Application of Information and Communication Technologies (AICT), Tashkent, Uzbekistan, 2020, pp. 1-6, doi: 10.1109/AICT50176. 2020. 9368817.

National report on anti-corruption policy of Kazakhstan. Available at: https://clck.ru/XecLc

Nazarbayev, N.A. (2018). Seven faces of the Great Steppe. Available at: https://clck.ru/XecLk

Nazarbayev, N. A. (2017) Vzgliad v budushchee: modernizatsiia obshchestvnnogo soznaniia [A look into the future: modernization of public consciousness]. Available at: https://clck.ru/QuMZJ

Nezdaiminova, E.A. (2019). Pedagogicheskaia aksiologiia. Pedagogicheskie tsennosti i ikh klassifikatsiia [Pedagogical axiology. Pedagogical values and their classification]. Available at: https:/clck.ru/XecLn

Resolution of the Government of the Republic of Kazakhstan dated February 9, 2021 No. 50. Available at: http://adilet.zan.kz/rus/docs/P2100000050

Pantyukhin, S.S. (2014). Poniatie pedagogicheskoi ideologii [The concept of pedagogical ideology].In Zapadno-Sibirskii pedagogicheskii vestnik. 1, 26-35. Available at: https://clck.ru/XecLr

Psychology of protest behavior. Available at: https://clck.ru/XecLx

Appeal of the Assembly of the People of Kazakhstan to the citizens of the country «Kazakhstani way 2050: common goal, common interests, common future» (2014). Available at: https://clck.ru/XecMV

Schwab, Klaus (2016). The Fourth Industrial Revolution. 230 p. Available at: https://clck.ru/XecMZ

Shiyanov, E.I. (1991). Humanization of pedagogical education: state and prospects. M., Stavropol, 1991.

Sultan Baybars. https://en.wikipedia.org/wiki/Baibars 
The programmatic article of the Head of State «Looking into the future: modernization of public consciousness» was published on April 12, 2017.Available at: https:/www.inform.kz/lenta/ruhani/ru/

The meaning of the word «self-identification» https://clck.ru/XecNS

Vershlovskij S. G. Osobennosti soczial'no-professional'ny'kh orientaczij uchitelej. Razvitie soczial'noprofessional'noj aktivnosti uchitelej na razny'kh e'tapakh deyatel'nosti: Sb. nauch. tr. M.: Izd-vo APN SSSR, 1990. S. 5-24.

Zakharov, A. (2013). Psikhologiia protesta [Protest Psychology]. In Vedomosti. Available at: https://www.vedomosti.ru/opinion/articles/2013/01/17/psihologicheskaya_logika_protesta 11

Zhetpisbayeva, B.A., Zhilbayev, Z.O., Syrymbetova, L.S., Dyakov, D.V.\& Muratova, L.M. (2020). Spiritual Modernisation of Student Youth. In Journal of Siberian Federal University. Humanities \& Social Sciences. 2020 13(2): 258-267. DOI: 10.17516/1997-1370-0557 